\title{
METHOD FOR SELECTING A CLASSIFIED TRAINING SAMPLE FOR RADAR'S ELEVATION CHANNELS
}

Semenov D. S. - Chief designer of surveillance radars of Scientific and Technical Department State Enterprise "Scientific and Production Complex "Iskra", Zaporizhzhia, Ukraine.

Piza D. M. - Dr. Sc., Professor, Professor of Radio Engineering Department, National University "Zaporizhzhia Polytechnic", Zaporizhzhia, Ukraine.

\begin{abstract}
Context. Under conditions of simultaneous exposure to active and passive interference, the passive component decorrelates the active component of the combined interference in the receiving channels of the surveillance radar, which significantly reduces the effectiveness of its suppression. Therefore, in order to adapt the weight coefficients of the spatial filter during spatio-temporal processing of radar signals, it is necessary, by one method or another, to form a classified training sample generated only by active noise interference.

Objective. The goal is to optimize the choice of a method for generating a classified training sample for various elevation channels of the radar field of view, taking into account the predicted distribution of passive interference in range.

Method. An analytical assessment of the distribution of the most powerful $\mathrm{Cb}$ type cumulonimbus cloud systems, followed by mathematical modeling of the effectiveness of the active noise suppression using various training samples generation methods.

Results. Based on the performed analytical calculations, it was shown that in the upper part of the field of view of surveillance radar in the sector of elevation angles from $6^{\circ}$ to $30^{\circ}$, the upper boundary of $\mathrm{Cb}$ type clouds does not exceed $75 \mathrm{~km}$, which guarantees the absence of passive interference at the end of the radar range. This makes it possible to form a training sample at a time interval located before the radiation of the next probe pulse. In the lower part of the field of view in the sector of angles $0^{\circ}$ to $6^{\circ}$, the upper boundary of the clouds is located at a distance of $75-270 \mathrm{~km}$, which does not allow the formation of a training sample at the end of the radar range. It is proposed to use the correlation method, in which the time interval for the formation of the training sample is determined by the "on the fly" analysis of the magnitude of the inter-channel correlation coefficient. The choice of the interval with the highest value of inter-channel correlation during the repetition period allows us to form a training sample with the least influence of passive interference on the process of suppressing the active component of the combined interference. As a result of modeling, it was found that the use of a training sample significantly reduces the duration of the transient process when forming the weight coefficients of the spatial filter and, accordingly, improves the quality of the suppression of active interference.

Conclusions. The scientific novelty of the work lies in the fact that for the first time the problem of individual selection of a classified training sample for the surveillance radar elevation channels has been solved. Practical significance consists in the development of a methodology for analyzing the location of the most powerful cloud systems in range in the radar field of view with varying degrees of influence of passive interference in elevation channels in a real signal-noise environment. To the practical novelty should also include the results of simulation modeling, which confirm the need to choose a method for generating a classified training sample in different elevation channels of the radar viewing area should also be attributed.
\end{abstract}

KEYWORDS: combined interference, classified training sample, modeling, inter-channel correlation coefficient modulus.

ABBRE
JK - jamming canceller;

ANI - active noise interference;

CTS - classified training sample;

MICC - magnitude of the inter-channel correlation coefficient;

PI - passive interference;

$\mathrm{SF}$ - spatial filter.

\section{NOMENCLATURE}

$h$ - height of the upper limit of clutter;

$h_{0}$ - radar position height above ground level;

$\dot{k}$ - complex value of the weight coefficient;

$R_{3}$ - Earth radius;

$\dot{U}_{0}$ - complex value of the interference voltage in the main channel;

$\dot{U}_{K}$ - complex value of the interference voltage in the compensation channel;

$|\dot{\rho}|$ - inter-channel correlation coefficient modulus;

$$
\sigma_{A \Pi}^{2}-\text { jamming variance. }
$$

\section{INTRODUCTION}

In real-world operating conditions, both active noise interference and passive interference (PI) can affect a radar [1]. An active noise interference (jamming) is created by sources of independent continuous noise emissions located in the far zone of the antenna, such sources are point-like in range and angular coordinates. Passive interference (clutter) is a radar signal reflected from the underlying surface of the Earth, hydrometeors or chaff and is non-stationary in nature. With the combined effect of the jamming and passive interference, the passive interference decorrelates the active component of the combined interference in the receiving channels of the radar $[2,3]$. Under these conditions, in the distance sections in the angular directions where the passive interference is predominant, the compensation of active interference becomes problematic [4]. In addition, the presence of passive interference, which in the general case has nonstationary nature, leads to a significant delay of transients 
during adaptation of spatial filters $[4,5]$. This is due to the degradation of the SF weighting coefficients when compensating for active interference at the range intervals over which the PI operates. In [6], an attempt was made under the conditions of combined interference to apply the alternate adaptation of the subsystems of spatial and temporal radar signals processing. However, the random nature of the passive interference distribution at range intervals did not allow to obtain a significant improvement in radar noise immunity.

Thus, in order to effectively suppress the active component of the combined interference in elevation channels, it is necessary to form a classified training sample generated only by the active interference.

\section{PROBLEM STATEMENT}

There are various methods for the formation of CTS [7]. For the formation of CTS, time, frequency or correlation differences in the structure of active and passive interference can be used. In real conditions of radar functioning, elevation channels are affected to varying degrees by passive interference. In the lower elevation channels, passive interference reflected from the underlying surface of the Earth has a greater effect. In the upper elevation channels, interference reflected from hydrometeors or chaff has a greater effect.

Thus, for the design of interference suppression systems, it is necessary to optimize the choice of methods for the formation of CTS. It is also necessary to take into account the general laws of the distribution of cloud systems in the Earth's atmosphere [8], which affect the distribution of passive interference in range in elevation channels. The task solved in this article is to develop a methodology for choosing methods of forming a classified training sample in elevation channels of a typical surveillance radar.

\section{REVIEW OF THE LITERATURE}

A number of publications are devoted to improving the efficiency of spatio-temporal processing of radar signals under the influence of combined interference. The most promising of them are adaptive systems capable of automatically suppressing active interference signals without a priori information about the interference environment, improving the reception of a useful signal [9]. However, with the simultaneous exposure to jamming and clutter, the efficiency of existing adaptive systems of spatio-temporal processing significantly deteriorates due to jamming decorrelation by clutter.

In many well-known technical solutions, it is proposed to use a fixed time interval located at the end of the radar range for the formation of a CTS [11, 12]. The proposed technical solutions are based on the a priori assumption that the intensity of passive interference decreases with increasing range. Moreover, the presence of a fixed interval simplifies the implementation of the method.

However, with spatially distributed cumulonimbus cloud systems of type $\mathrm{Cb}$, the intensity of the reflected sig- nals at the maximum range of the radar in the lower elevation channels of the field of view can significantly exceed the inherent noise of the receiver, as well as the level of the ANI. This does not allow effective suppression of the active component of the combined interference.

In [13], a method for generating a CTS was proposed, in which the calculation of weighting coefficients is performed in the frequency range shifted relative to the working frequency range of the radar. However, due to the differences in the central frequencies of the interference used to form the SF weighting coefficients and the center frequency of the spectrum of the useful radar signal, the suppression coefficient of the ANI deteriorates significantly [13]. To increase the ANI suppression coefficient at the signal frequency, an automatic measurement of the phase difference due to the frequency difference between the ANI and the signal, with the subsequent adjustment of the noise phase in the compensation channel, was proposed in [14]. This significantly complicated the implementation of the proposed method.

In $[15,16]$, a correlation method was proposed for generating a classified training sample, using the natural non-stationarity of passive interference in time (in range). Such non-stationarity is characteristic of signals reflected both from hydrometeors and from chaff cloud, which have a point-like character. The proposed method is based on the use of a posteriori information regarding the distribution of passive interference in range.

Taking into account the fact that under the influence of both ANI and passive interference, the passive interference decorrelates the signals generated by a point source of ANI in the receiving channels of the radar, it seems possible to estimate the distribution of the module of the interchannel correlation coefficient over the range sections. In this case, according to the known values of the MICC, a time interval is selected for adapting the weight coefficients of the jamming canceller with the maximum correlation value, which corresponds to the lowest level (or absence) of passive interference.

MICC $|\dot{\rho}|$ can be calculated using the "sliding window" method at intervals consisting of $m$ range samples

$$
|\dot{\rho}|=\frac{\overline{\left|\dot{U}_{0} \dot{U}_{k}^{*}\right|}}{\sqrt{\left|\overline{\dot{U}_{0}^{2}}{ }^{2}\right|\left|\dot{U}_{k}^{2}\right|}}
$$

The number of samples $m$ to be averaged in expression (1) is determined by the adaptation time of the spatial filter weight coefficients. If in the expression for calculating the weighting coefficient of jamming canceller $\dot{k}=\overline{\dot{U}_{0} \dot{U}_{k}^{*}} \cdot\left(\overline{\dot{U}_{k} \dot{U}_{k}^{*}}\right)^{-1}$, as well as in the expression for MICC (1), the averaging intervals are the same, then the calculation of the weight coefficient and MICC are performed in parallel and synchronously. Thus, the possibility of real-time radar operation is provided. For example, 
with a useful signal duration of $1 \mu$ s, the duration of the transient process during the formation of the weight coefficient, and, accordingly, the formation of the MICC, can be approximately $10 \mu \mathrm{s}$.

\section{MATERIALS AND METHODS}

Taking into account the variety of methods for generating CTS and the varying amount of passive interference in elevation radar channels, it seemed appropriate to develop a methodology for selecting methods for generating CTS in elevation channels of surveillance radars during their design or modernization.

The morphological classification of clouds consists of 10 forms, 20 species and 36 varieties [8]. In this regard, it seems advisable to consider only those types of clouds that can cover a significant part of the radar field of view in azimuth, range and altitude, creating the most difficult conditions for the operation of SF. The main data on these types of clouds are given in table 1 . From the table 1 it follows that the most difficult conditions for the operation of SF arise when exposed to passive interference reflected from cumulonimbus clouds of the species $\mathrm{Cb}$.

Table 1 - Data on the considered forms of clouds

\begin{tabular}{|l|c|c|c|}
\hline Abbrevition & Type & $\begin{array}{c}\text { The height of the } \\
\text { lower boundary, } \mathrm{km}\end{array}$ & $\begin{array}{c}\text { Layer thickness, } \\
\mathrm{km}\end{array}$ \\
\hline $\mathrm{As}$ & altostratus & $2 \ldots 6$ & $1 \ldots 2$ \\
\hline $\mathrm{Sc}$ & stratocumulus & $0.5 \ldots 1.5$ & $0.2 \ldots 0.8$ \\
\hline $\mathrm{Ns}$ & nimbostratus & $0.5 \ldots 1.9$ & $2 \ldots 3$ \\
\hline $\mathrm{Cb}$ & cumulonimbus & $0.6 \ldots 1.2$ & $3 \ldots 8$ \\
\hline
\end{tabular}

Let us analyze the location of the passive interference layer reflected from $\mathrm{Cb}$ types clouds on the radar's range depending on the elevation of the radar beam and the height of the position of the radar above sea level.

Let us consider the geometry of the problem (Fig. 1) on the plane containing the center of the Earth $\mathrm{C}$ and the radar's beam OA. Earth's surface can be approximately represented by a circle of radius $\mathrm{R} 3$. Let the height of the position of the radar above sea level be - h0 , height of the upper limit of passive interference $-\mathrm{h}$. In this case, the upper limit of passive interference can be represented by a circle with the center at the point $\mathrm{C}$ with a radius of $\mathrm{R} 3+\mathrm{h}$. The point of intersection of a radar beam with a circle of radius $\mathrm{R} 3+\mathrm{h}$ corresponds to point $\mathrm{A}$ in Fig. 1 .

It is necessary to determine the position of the upper limit of passive interference on the radar range scanning, i.e. determine the length of the segment OA.

Let's introduce a polar coordinate system with a pole in point $\mathrm{O}$ and a polar axis $\mathrm{OM}$, corresponding to zero elevation. Let the angle of the point $\mathrm{A}$ be denoted as $\theta$. The equation of a circle of radius a with center at the point $(\mathrm{r} 0, \theta 0)$ in the polar coordinate system $r, \varphi$ is defined as [12]:

$$
r^{2}-2 r r_{0} \cos \left(\varphi-\theta_{0}\right)+r_{0}^{2}=a^{2}
$$

where $r$ is the polar radius; $\varphi-$ polar angle; $\left(r_{0}, \theta_{0}\right)-$ coordinates of the center of the circle.

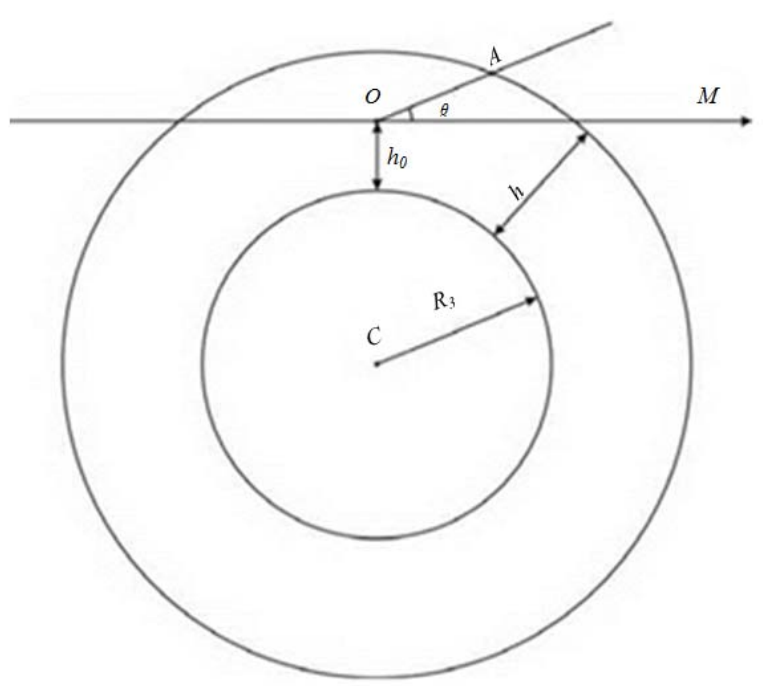

Figure 1 - Geometry of the problem

Taking into account (2), the coordinates of the center of the Earth $C\left(R_{3}+h_{0},-90^{\circ}\right)$ and the notation introduced, the equation of the circle corresponding to the upper limit of the passive interference is defined as:

$$
\begin{aligned}
& r^{2}-2 r\left(R_{3}+h_{0}\right) \cos \left(90^{\circ}+\varphi\right)+\left(R_{3}+h_{0}\right)^{2}=\left(R_{3}+h\right)^{2}, \\
& r^{2}+2 r\left(R_{3}+h_{0}\right) \sin \varphi+\left(R_{3}+h_{0}\right)^{2}-\left(R_{3}+h\right)^{2}=0 .
\end{aligned}
$$

or

Since the polar angle $\varphi$ coincides with the elevation angle $\theta$ in the introduced coordinate system, the desired segment $\mathrm{OA}$ is determined by solving equation (4) with respect to the substitution $\varphi=\theta$.

The discriminant of an equation is defined as:

$$
D / 4=\sqrt{\left(R_{3}+h_{0}\right)^{2} \sin ^{2} \theta-\left(R_{3}+h_{0}\right)^{2}+\left(R_{3}+h\right)^{2}} .
$$

By the condition of the problem $h>h_{0}$, therefore, the discriminant (4) will be positive, and equation (4) will have two real roots:

$$
\frac{r_{1,2}=-\left(R_{3}+h_{0}\right) \sin \theta \pm}{ \pm \sqrt{\left(R_{3}+h_{0}\right)^{2} \sin ^{2} \theta-\left(R_{3}+h_{0}\right)^{2}+\left(R_{3}+h\right)^{2}}} .
$$

An analysis of expression (6) and the conditions of the problem shows that only a positive root will be its solution, while the second (negative) root will correspond to the second intersection point of the OA line (containing the radar beam) with the circle. Finally we have:

$$
\begin{gathered}
O A=\sqrt{\left(R_{3}+h_{0}\right)^{2} \sin ^{2} \theta-\left(R_{3}+h_{0}\right)^{2}+\left(R_{3}+h\right)^{2}}- \\
-\left(R_{3}+h_{0}\right) \sin \theta .
\end{gathered}
$$




\section{EXPERIMENTS}

Let us apply the obtained dependence of the distance on the height of the border of passive interference (PI) to the radar 36D6 of Ukrainian production, which is used in air defense systems in many countries of the world. The radar has two fields of view in elevation, called "lower" $\left(0 \ldots 6^{\circ}\right)$ and "upper" $\left(6 \ldots 30^{\circ}\right)$. The values of angles in elevation of the radar beams are given in table 2 .

Table 2 - The values of angles in elevation of the radar 36D6 beams

\begin{tabular}{|c|c|c|}
\hline \multirow{2}{*}{ Beam number } & \multicolumn{2}{|c|}{ Elevation angle, degree } \\
\cline { 2 - 3 } & Lower field of view & Upper field of view \\
\hline 1 & 0.75 & 9 \\
\hline 2 & 2.25 & 15 \\
\hline 3 & 3.75 & 21 \\
\hline 4 & 5.25 & 27 \\
\hline
\end{tabular}

The dependence of the distance on the height of the upper boundary of passive interference (clouds of $\mathrm{Cb}$ type, as shown it table 1) for the elevation beams of the 36D6 radar is shown in Fig. 2 (upper zone) and Fig. 3 (lower zone).

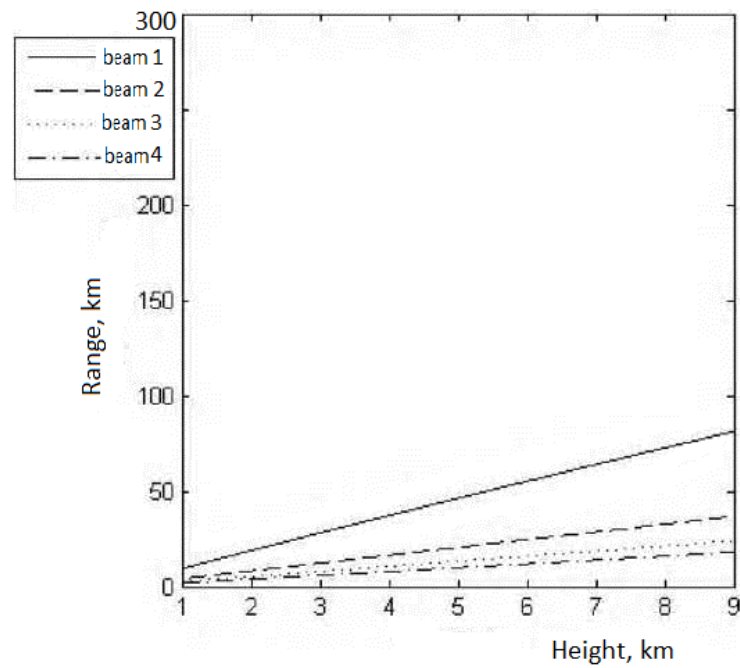

Figure 2 - The dependence of the distance on the height of the upper boundary of passive interference for the upper zone

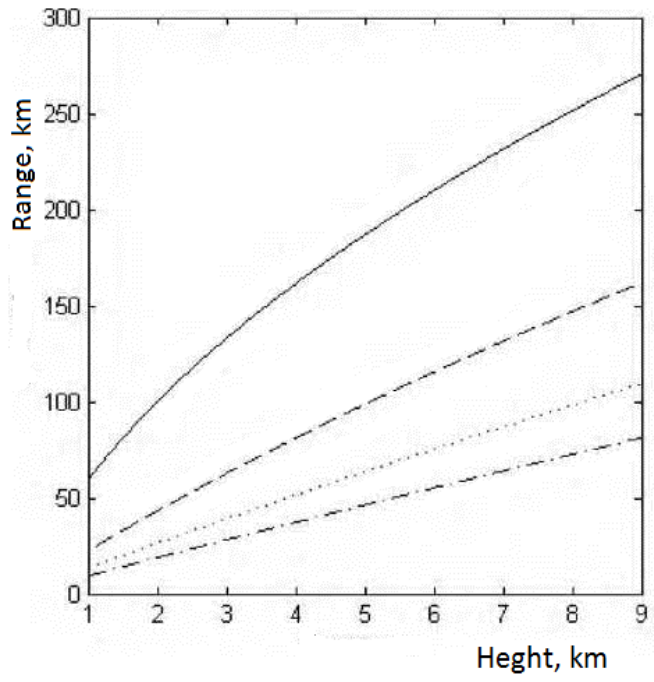

Figure 3 - The dependence of the distance on the height of the upper boundary of passive interference for the lower zone (C) Semenov D. S., Piza D. M., 2020 DOI 10.15588/1607-3274-2020-1-4
Analysis of Fig. 2 shows that with the height of the upper limit of passive interference equal to $9 \mathrm{~km}$, at the end of the range there will be an area free from interference for the formation of CTS. So, for example, for the 1 st beam of the upper zone, the upper limit of passive interference will correspond to a distance of about $75 \mathrm{~km}$ $75 \mathrm{kм}$, for the $2 \mathrm{nd}$ one $-35 \mathrm{~km}$, for the $3 \mathrm{rd}$ and $4 \mathrm{th}-25$ and $20 \mathrm{~km}$.

As follows from Fig. 3, the upper boundary of $\mathrm{Cb}$ type clouds in 1-4 beams of the lower zone will be located at a distance from 70 to $270 \mathrm{~km}$. Therefore, the formation of CTS in the elevation channels of the lower zone of the 36 D6 radar according to the method proposed in $[11,12]$ cannot be ensured under real operating conditions.

An acceptable method for the formation of CTS in the elevation channels of the lower zone may be the correlation method proposed in $[15,16]$. In the proposed method, a real-time "on the fly" estimation of PI distribution in range in each elevation channel is carried out. Such estimation is made by calculating the MICC for the range interval. Moreover, taking into account the natural unsteadiness of the PI in range, CTS is formed in the time interval with the maximum value of the MICC, at which the PI has the lowest level.

\section{RESULTS}

The Simulation of a spatial filter was carried out in graphical extension SimuLink of MATLAB computing environment. The simulation was carried out for the case when the active noise interference affected the direction of the side lobes of the antenna pattern of the main channel. In this case, in the direction of the active noise interference source, the gain of the compensation antenna was equal to the gain along the side lobe of the main antenna. Passive interference was acting from the direction of the main lobe of the antenna pattern of the main channel. The gain of the main antenna was $20 \mathrm{~dB}$ higher than the gain of the compensation antenna.

Under these conditions of external influences on the spatial filter, interference signals in the reception channels were set as follows:

- the ratio of the active interference dispersions to the noise dispersion in the reception channels is equal in the interval equal to the inter-pulse period;

- the ratio of the dispersion of passive interference to the dispersion of noise: in the main channel is $30 \mathrm{~dB}$, in the compensation channel is $10 \mathrm{~dB}$;

- passive interference was set at intervals $(0-50)$ and $(300-400) \mu$ s within the inter-pulse period. In this case, the dispersion of passive interference at the intervals of the range within the inter-pulse period varied within $3 \mathrm{~dB}$.

The following parameters were monitored during the simulation:

- waveforms of signals at the input and output of the spatial filter;

- the magnitude of the inter-channel correlation coefficient;

- the magnitude of the weighting coefficient;

- active noise interference cancellation ratio. 
Under the specified modeling conditions, for the dispersion of active noise $\sigma_{A \Pi}^{2}$ in reception channels equal to $10 \mathrm{~dB}$, we got the results are presented as shown in Fig. 4-7:

- in Fig. 4 shows the signal $\dot{U}_{0}$ acting at the input of the main channel of the spatial filter in the current interpulse period $(0-500) \mu$ s. An signal with compensated active influence is also shown, acting at the output of the spatial filter in the next inter-pulse period $(500-1000 \mu \mathrm{s})$. Such latency occur due to the delay of the $\dot{U}_{0}$ and $\dot{U}_{K}$ signals for the CTS formaion time.

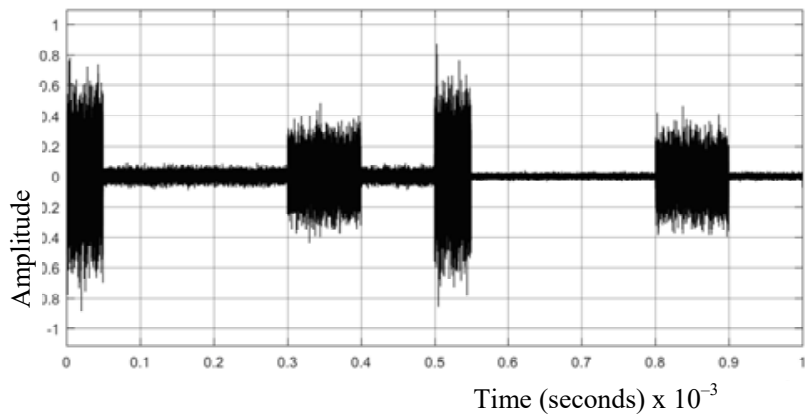

Figure $4-$ The signal at the main input $(0-500) \mu$ s and at the output (500-1000) $\mu$ s of spatial filter

- Fig. 5-8 show the distributions of the normalized MICC $|\dot{\rho}|$, the weighting coefficient magnitude $|\dot{k}|$ and the interference cancellation ratio $K_{\Pi}$ on the interval $(0$ 500) $\mu \mathrm{s}$, where the classified training sample is formed, as well as on the interval (500-1000) $\mu \mathrm{s}$, where it is used. From Fig. 5 it follows that the maximum value of $|\dot{\rho}|$ in the interval $(0-500) \mu \mathrm{s}$ of the current inter-pulse period is reached at a time moment corresponding to $300 \mu \mathrm{s}$. At the end of the current inter-pulse period, in accordance with the proposed algorithm, the formed weighting coefficient $\dot{k}_{\text {onm }}$ is selected according to the maximum $|\dot{\rho}|_{\max }$ value to compensate the active interference delayed in the delay lines of the spatial filter for the one repetition period.

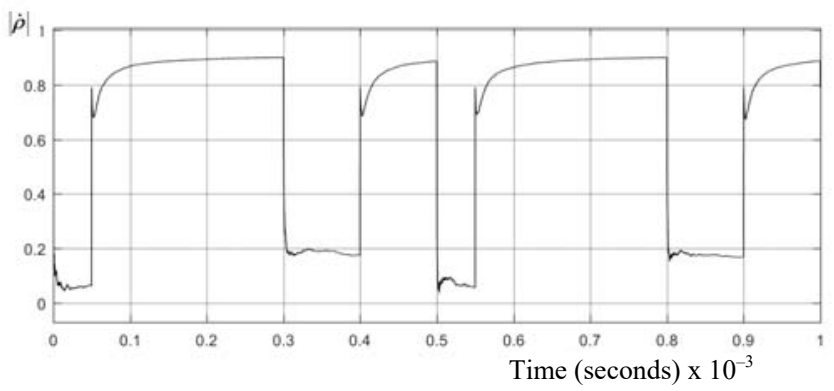

Figure 5 - The distribution of the normalized MICC at intervals of formation (0-500) $\mu$ s and using (500-1000) $\mu$ s of the training sample

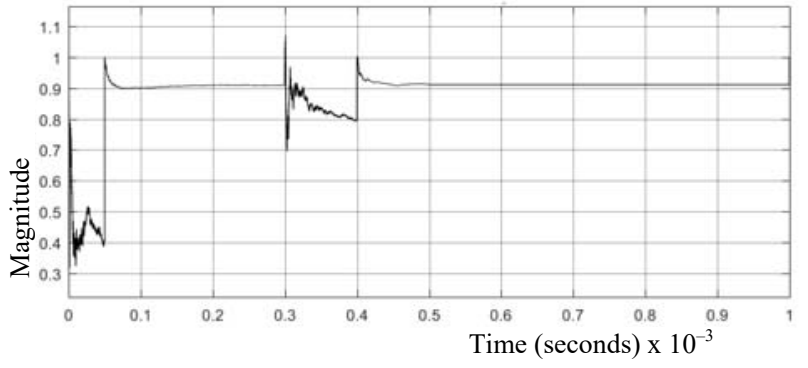

Figure 6 - The distribution of the weighting coefficient magnitude at intervals of formation $(0-500) \mu$ s and using $(500-1000)$ $\mu$ s of the training sample

From Fig. 6 (with $\sigma_{A I}^{2}$ equal to $10 \mathrm{~dB}$ ) and Fig. 8 (with $\sigma_{A I}^{2}$ equal to $30 \mathrm{~dB}$ ) it follows that at intervals of the presence of passive interference (0-50) $\mu$ s and (300400) $\mu \mathrm{s}$, the weight coefficient modulates it, violating the inter-period correlation. After the formation of a classified training sample by the proposed method, the modulation of passive interference does not occur.

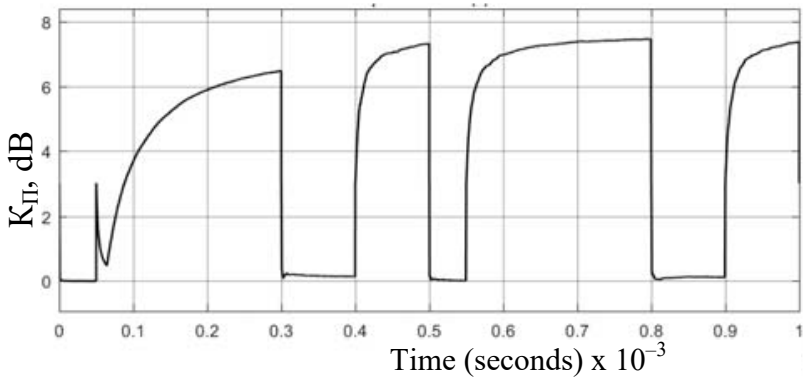

Figure 7 - The distribution of the cancellation ratio at intervals of formation (0-500) $\mu$ s and using (500-1000) $\mu$ s of the training sample

In Fig. 7 shows the efficiency of active interference suppression both on the interval of training sample formation and on the interval of its use (as the dependence of the suppression coefficient vs. time) The decrease in the suppression coefficient at the intervals of $(0-50) \mu$ s and (300-400) $\mu$ s during the formation of the CTS, as well as at the intervals (500-550) $\mu$ s and (800-900) $\mu$ s when we using CTS, is explained by decorrelation of the active interference by passive interference, which is confirmed by Fig. 1 .

This is determined by the excess of passive interference over active. Comparison of the time of increase in the suppression coefficient during the formation of CST (starting from the 50th microsecond) and when using CST (starting from the 550th microsecond) shows that after the formation of the training sample, the duration of the transition process decreases significantly. So, during the formation of the training sample, the duration of the transition process (until the coefficient of suppression reaches the value $K_{\Pi}=6 \mathrm{~dB}$ ) is $200-50=150 \mu \mathrm{s}$.

In the interval of using the CST, the duration of the transition process (until the coefficient of suppression 
reaches the value $K_{\Pi}=6 \mathrm{~dB}$ ) is $575-550=25 \mu \mathrm{s}$. Based on the results obtained, it can be considered that under the conditions of unsteady passive interference, the proposed method for processing radar signals will increase the radar interference immunity.

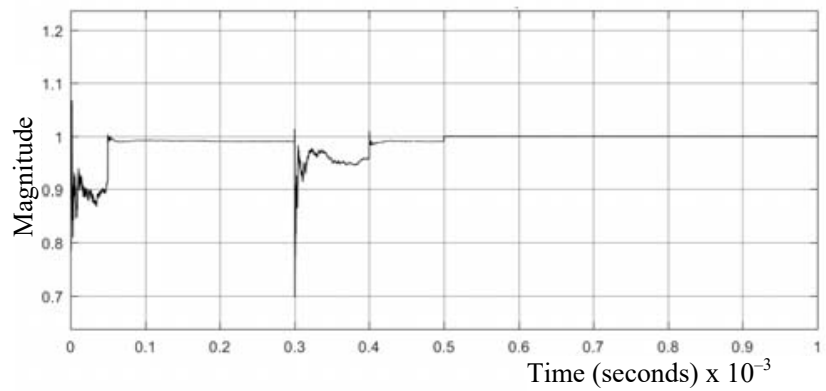

Figure 8 - The distribution of the cancellation ratio at intervals of formation (0-500) $\mu$ s and using (500-1000) $\mu$ s of the training sample with active interference variance $\sigma_{A \Pi}^{2}=30 \mathrm{~dB}$

\section{DISCUSSION}

A comparative analysis of two methods for forming a classified training sample based on the general distribution pattern in space of the most powerful $\mathrm{Cb}$ type cumulonimbus clouds showed that it is necessary to use different methods to increase interference immunity in different elevation channels. So, in the upper part of the field of view it is rational to use the a priori method, i.e. use the time interval located at the end of the radar range, with a guaranteed absence of passive interference. In the lower part of the field of view, where such an interval is absent, the a posteriori method with the "on the fly" correlation analysis of the presence/absence of passive interference at range intervals is more preferable.

In this case, by choosing the interval with the highest value of MICC, you can select the time interval with the lowest level of passive interference to adapt the weight coefficient of the spatial filter.

\section{CONCLUSIONS}

Based on the performed analytical calculations, it was shown that in the upper part of the field of view of surveillance radar in the sector of elevation angles from $6^{\circ}$ to $30^{\circ}$, the upper boundary of $\mathrm{Cb}$ type clouds does not exceed $75 \mathrm{~km}$, which guarantees the absence of passive interference at the end of the radar range. This makes it possible to form a training sample at a time interval located before the radiation of the next probe pulse. In the lower part of the field of view in the sector of angles $0^{\circ}$ to $6^{\circ}$, the upper boundary of the clouds is located at a distance of 75 $270 \mathrm{~km}$, which does not allow the formation of a training sample at the end of the radar range.

It is proposed to use the correlation method, in which the time interval for the formation of the training sample is determined by the "on the fly" analysis of the magnitude of the interchannel correlation coefficient. The choice of the interval with the highest value of inter-channel correlation during the repetition period allows us to form a training sample with the least influence of passive interference on the process of suppressing the active component of the combined interference. As a result of modeling, it was found that the use of a training sample significantly reduces the duration of the transient process when (C) Semenov D. S., Piza D. M., 2020 DOI 10.15588/1607-3274-2020-1-4 forming the weight coefficients of the spatial filter and, accordingly, improves the quality of the suppression of active interference.

\section{ACKNOWLEDGEMENTS}

The paper was conducted within the framework of research project "Improving the efficiency of coherentpulse radar under difficult operating conditions" (№ 0117U0006) with the financial support of the Ministry of Education and Science of Ukraine.

\section{REFERENCES}

1. Shirman Ja. D., Golikov V. N., Busygin I. N. i dr. ; pod obshh. red. Ja. D. Shirmana. Teoreticheskie osnovy radiolokacii : ucheb. posobie dlja vuzov. Moscow, Sov. radio, $1970,560 \mathrm{p}$.

2. Zhuravlev A. K., Hlebnikov V. A., Rodimov A. P. Adaptivnye radiotehnicheskie sistemy s antennymi reshetkami. Leningrad, Izd. Leningradskogo universiteta, 1991, 544 p.

3. Piza D. M., Romanenko S. N., Semenov D. S. Korreljacionnyj metod formirovanija obuchajushhej vyborki dlja adaptacii prostranstvennogo fil'tra, Radio Electronics, Computer Science, Control, 2018, No. 3, pp. 34-39. DOI: 10.15588/1607-3274-2018-3-4.

4. Grigor'ev V.V. Kombinirovannaja obrabotka signa-lov v sistemah radiosvjazi. Moscow, JeKO-TRENDZ, 2002, $262 \mathrm{p}$.

5. Abramovich Ju.I. Predel'naja skorost' shodimosti processov adaptivnoj nastrojki sistem kompensacii pomeh v uslovijah neklassifici-rovannoj obuchajushhej vyborki, Radiotehnika $i$ jelektronika, 1982, Vyp. 8, pp. 1534-1538.

6. Abramovich Ju. I., Kachur V. G. Bystrodejstvie poocherednoj nastrojki razdel'nyh sistem zashhity ot kombinirovannyh pomeh, Radiotehnika i jelektronika, 1969, Vyp. 1, pp. $52-58$

7. Piza D. M., Moroz G. V Metody formirovanija klassificirovannoj obuchajushhej vyborki dlja adaptacii vesovyh kojefficientov avtokompensatora pomeh, Izvestija vysshih uchebnyh zavedenij. Radiojelektronika, 2018, No. 1, pp. 47-54 DOI: $10.20535 / 80021347016060030$.

8. Bespalov D. P. i dr.; red.: Surygina L. K. Atlas oblakov / Feder. Sluzhba po gidrome-teorologii i monitoringu okruzhajushhej sredy (Rosgidromet), Gl. geofiz. observatorija im. A.I. Voejkova. Sankt-Peterburg, D'ART, 2011, 248 p.

9. Lehovickij D. I. Adaptivnye reshetchatye fil'try dlja sistem prostranstvenno-vremennoj obrabotki nestacionarnyh gaussovyh processov, Izvestija vysshih uchebnyh zavedenij. Radiojelektronika, 2018, No. 11, pp. 607-642. DOI: $10.20535 / \mathrm{S} 0021347018110018$.

10. Piza D. M., Semenov D. S., Morshhavka S. V. Ocenka jeffektivnosti diskretnyh algoritmov adaptacii vesovyh kojefficientov pri prostranstvenno-vremennoj obrabotke radiolokacionnyh signalov, Izvestija vysshih uchebnyh zavedenij. Radiojelektronika, 2019, No. 1, pp. 8-15. DOI: 10.20535/S0021347019010023.

11. Ivlev D. N., Orlov I. Ja., Sorokina A. V., Fitasov E. S. Adaptivnye algoritmy kompensacii pomeh : uchebnometodicheskoe posobie ; Min-vo obrazovanija i nauki RF, Nizhnenovgorodskij gos. universitet im. N. I. Lobachevskogo. Nizhnij Novgorod, NNGU im. N. I. Lobachevskogo, 2014, $87 \mathrm{p}$

12. Sposib kompensacii' aktyvnoi' skladovoi' kombinovanoi' zavady: pat. 48705 Ukrai'na: MPK G01S 7/36. № 
u200911296; zajavl. 06.11.2009; opubl. 25.03.2010, Bjul. № 6 .

13. Anohin V. D., Simohammed Vauzi, Kil'djushhevskaja V. G. Obrabotka radiolokacionnyh signalov na fone kombinirovannyh pomeh. Moscow, Radiotehnika, 2009, No. 5, pp. 133-136.

14. Ustrojstvo kompensacii aktivnyh pomeh: pat. 2444751 Rossijskaja federacija: MPK G01S 7/36. №2009108762/09; zajavl. 10.03.2009; opubl. 10.03.2012.

15. Sposib zahystu kogerentno-impul'snyh radiolokacijnyh stancij vid kombinovanyh zavad: pat. 78120 Ukrai'na: MPK
G01S 7/36. № u201210218; zajavl. 28.08.2012; opubl. 11.03.2013, Bjul. №5.

16. Piza D. M., Lavrent'ev V. N., Semenov D. S. Metod formirovanija klassificirovannoj obuchajushhej vyborki dlja avtokompensatora pomeh pri vremjapro-stranstvennoj fil'tracii signalov, Izvestija vysshih uchebnyh zavedenij. Radiojelektronika, 2016, No. 3, pp. 18-22. DOI 10.15588/1607-32742016-3-2.

17. Korn G. Spravochnik po matematike dlja nauchnyh rabotnikov i inzhenerov. Moscow, Nauka, 1973, 832 p.

\section{УДК 621.396 .95}

МЕТОД ВИБОРУ КЛАСИФІКОВАНОЇ НАВЧАЛЬНОЇ ВИБІРКИ ДЛЯ КУТОМІСЦЕВИХ КАНАЛІВ РЛС

Семенов Д. С. - головний конструктор оглядових радарів Центру Досліджень і Конструювання Казенного підприємства «Науково-виробничий комплекс «Іскра», м. Запоріжжя, Україна.

Піза Д. М. - д-р техн. наук, професор кафедри Радіотехніка та телекомунікації Національного університету «Запорізька політехніка», м. Запоріжжя, Україна.

\section{АНОТАЦІЯ}

Актуальність. При одночасному впливі активної і пасивної завади остання декорелює активну складову комбінованої завади в прийомних каналах РЛС виявлення і супроводу, що істотно знижує ефективність ії компенсації. Тому при просторово-часовій обробці радіолокаційних сигналів необхідно тим чи іншим методом сформувати класифіковану навчальну вибірку, породжену тільки активною шумовою завадою для адаптації вагових коефіцієнтів просторового фільтра.

Метод. Аналітична оцінка розподілу найбільш потужних купчасто-дощових хмарних систем виду Сb 3 подальшим математичним моделюванням ефективності придушення активних завад 3 використанням різних методів формування навчальної вибірки.

Результати. На підставі проведених аналітичних розрахунків показано, що у верхній частині зони огляду типової РЛС виявлення і супроводу в секторі кутів місця від $6^{\circ}$ до $30^{\circ}$ верхня межа хмар виду $\mathrm{Cb}$ не перевищує 75 км, що гарантує відсутність пасивних завад в кінці дальності дії РЛС. Це дозволяє сформувати навчальну вибірку на часовому інтервалі, розташованому перед випромінюванням чергового зондуючого імпульсу. У нижній частині зони огляду в секторі кутів $0^{\circ}$ до $6^{\circ}$ верхня межа хмар розташовується на дальності 75-270 км, що не дозволяє сформувати навчальну вибірку в кінці дальності дії РЛС. Запропоновано використовувати кореляційний метод, при якому часовий інтервал для формування навчальної вибірки визначається шляхом поточного аналізу величини модуля міжканального коефіцієнта кореляції. Вибір інтервалу 3 найбільшим значенням міжканальної кореляції протягом періоду повторення дозволяє сформувати навчальну вибірку 3 найменшим впливом пасивної завади на процес компенсації активної складової комбінованої завади. В результаті моделювання встановлено, що використання навчальної вибірки істотно зменшує тривалість перехідного процесу при формуванні вагових коефіцієнтів просторового фільтра і, відповідно, покращує якість придушення активної завади.

Висновки. Наукова новизна роботи полягає в тому, що вперше вирішена задача індивідуального вибору класифікованої навчальної вибірки для кутомісцевих каналів РЛС виявлення і супроводу.

Практичне значення полягає в розробці методики аналізу розташування найбільш потужних хмарних систем по дальності в зоні огляду РЛС з різним ступенем ураження кутомісцевих каналів пасивними завадами у реальній сигнальнозавадовій обстановці. До практичної новизни також слід віднести результати імітаційного моделювання, які підтверджують необхідність вибору методу формування класифікованої навчальної вибірки в різних кутомісцевих каналах зони огляду РЛС.

КЛЮЧОВІ СЛОВА: комбінована завада, класифікована навчальна вибірка, моделювання, модуль міжканального коефіцієнта кореляції.

\section{УДК 621.396 .95}

\section{МЕТОД ВЫБОРА КЛАССИФИЦИРОВАННОЙ ОБУЧАЮЩЕЙ ВЫБОРКИ ДЛЯ УГЛОМЕСТНЫХ КАНАЛОВ РЛС}

Семенов Д. С. - главный конструктор обзорных радаров Центра Исследований и Конструирования Казенного предприятия «Научно-производственный комплекс «Искра», г. Запорожье, Украина.

Пиза Д. М. - д-р техн. наук, профессор кафедры Радиотехника и телекоммуникации Национального университета «Запорожская политехника», г. Запорожье, Украина.

\section{АННОТАЦИЯ}

Актуальность. При одновременном воздействии активной и пассивной помехи последняя декоррелирует активную составляющую комбинированной помехи в приемных каналах РЛС обнаружения и сопровождения, что существенно снижает эффективность ее компенсации. Поэтому при пространственно-временной обработке радиолокационных сигналов необходимо тем или иным методом сформировать классифицированную обучающую выборку, порожденную только активной шумовой помехой для адаптации весовых коэффициентов пространственного фильтра. 
Метод. Аналитическая оценка распределения наиболее мощных кучево-дождевых облачных систем вида Сb c последующим математическим моделированием эффективности подавления активных помех с использованием различных методов формирования обучающей выборки.

Результаты. На основании проведенных аналитических расчетов показано, что в верхней части зоны обзора типовой РЛС обнаружения и сопровождения в секторе углов места от $6^{\circ}$ до $30^{\circ}$ верхняя граница облаков вида Сb не превышает 75 км, что гарантирует отсутствие пассивных помех в конце дальности действия РЛС. Это позволяет сформировать обучающую выборку на временном интервале, расположенном перед излучением очередного зондирующего импульса. В нижней части зоны обзора в секторе углов $0^{\circ}$ до $6^{\circ}$ верхняя граница облаков располагается на дальности $75-270$ км, что не позволяет сформировать обучающую выборку в конце дальности действия РЛС. Предложено использовать корреляционный метод, при котором временной интервал для формирования обучающей выборки определяется путем текущего анализа величины модуля межканального коэффициента корреляции. Выбор интервала с наибольшим значением межканальной корреляции в течении периода повторения позволяет сформировать обучающую выборку с наименьшим влиянием пассивной помехи на процесс компенсации активной составляющей комбинированной помехи. В результате моделирования установлено, что использование обучающей выборки существенно уменьшает длительность переходного процесса при формировании весовых коэффициентов пространственного фильтра и, соответственно, улучшает качество подавления активной помехи.

Выводы. Научная новизна работы состоит в том, что впервые решена задача индивидуального выбора классифицированной обучающей выборки для угломестных каналов РЛС обнаружения и сопровождения.

Практическое значение состоит в разработке методики анализа расположения наиболее мощных облачных систем по дальности в зоне обзора РЛС с различной степенью поражения угломестных каналов пассивными помехами в реальной сигнально-помеховой обстановке. К практической новизне также следует отнести результаты имитационного моделирования, которые подтверждают необходимость выбора метода формирования классифицированной обучающей выборки в разных угломестных каналах зоны обзора РЛС.

КЛЮЧЕВЫЕ СЛОВА: комбинированная помеха, классифицированная обучающая выборка, моделирование, модуль межканального коэффициента корреляции.

\section{ЛІТЕРАТУРА / ЛИТЕРАТУРА}

1. Теоретические основы радиолокации : учеб. пособие для вузов / Я. Д. Ширман, В. Н. Голиков, И. Н. Бусыгин и др. ; под общ. ред. Я. Д. Ширмана. - М. : Сов. радио, 1970. $-560 \mathrm{c}$.

2. Журавлев А. К. Адаптивные радиотехнические системы с антенными решетками / А. К. Журавлев, В. А. Хлебников, А. П. Родимов. - Ленинград : Изд. Ленинградского университета, 1991. - 544 с.

3. Пиза Д. М. Корреляционный метод формирования обучающей выборки для адаптации пространственного фильтра. / Д. М. Пиза, С. Н. Романенко, Д. С. Семенов // Радиоэлектроника, информатика, управление. - 2018. № 3. - C. 34-39. DOI: 10.15588/1607-3274-2018-3-4.

4. Григорьев В. В. Комбинированная обработка сигналов в системах радиосвязи / В. В. Григорьев. - М. : ЭКОТРЕНДЗ, 2002. - 262 с

5. Абрамович Ю. И. Предельная скорость сходимости процессов адаптивной настройки систем компенсации помех в условиях неклассифицированной обучающей выборки / Ю. И. Абрамович // Радиотехника и электроника, 1982. - Вып. 8. - С. 1534-1538.

6. Абрамович Ю. И. Быстродействие поочередной настройки раздельных систем защиты от комбинированных помех/ Ю. И. Абрамович, В. Г. Качур // Радиотехника и электроника, 1969. - Вып. 1. - С. 52-58.

7. Пиза Д. М. Методы формирования классифицированной обучающей выборки для адаптации весовых коэффициентов автокомпенсатора помех / Д. М. Пиза, Г. В. Мороз // Известия высших учебных заведений. Радиоэлектроника. - 2018. - № 1. - C. 47-54 DOI: $10.20535 / 80021347016060030$.

8. Атлас облаков / Федер. Служба по гидрометеорологии и мониторингу окружающей среды (Рос-гидромет), Гл. геофиз. обсерватория им. А. И. Воейкова; [Д. П. Беспалов и др.; ред.: Л. К. Сурыгина]. - Санкт-Петербург : Д'АРТ, 2011. - 248 с.

9. Леховицкий Д. И. Адаптивные решетчатые фильтры для систем пространственно-временной обработки нестационарных гауссовых процессов / Д. И. Леховицкий //
Известия высших учебных заведений. Радиоэлектроника. - 2018. - № 11. - C. 607-642. DOI: $10.20535 / \mathrm{S} 0021347018110018$

10. Пиза Д. М. Оценка эффективности дискретных алгоритмов адаптации весовых коэффициентов при пространственно-временной обработке радиолокационных сигналов / Д. М. Пиза, Д. С. Семенов, С. В. Морщавка // Известия высших учебных заведений. Радиоэлектроника. 2019. - № $1 . \quad-\quad$ C. $8-15$. DOI: $10.20535 / \mathrm{S} 0021347019010023$.

11. Адаптивные алгоритмы компенсации помех : учебнометодическое пособие / [Д. Н. Ивлев, И. Я. Орлов, А. В. Сорокина, Е. С. Фитасов ]; Мин-во образования и науки РФ, Нижненовгородский гос. университет им. Н. И. Лобачевского. - Нижний Новгород : ННГУ им. Н. И. Лобачевского, 2014. - 87 с.

12. Спосіб компенсації активної складової комбінованої завади: пат. 48705 Україна: МПК G01S 7/36 . № u200911296; заявл. 06.11.2009; опубл. 25.03.2010, Бюл. №6.

13. Анохин В. Д. Обработка радиолокационных сигналов на фоне комбинированных помех / В. Д. Анохин, Ваузи Симохаммед, В. Г. Кильдющевская // Радиотехника. 2009. - № 5. - С. 133-136.

14. Устройство компенсации активных помех: пат. 2444751 Российская федерация: МПК G01S 7/36 №2009108762/09; заявл. 10.03.2009; опубл. 10.03.2012.

15. Спосіб захисту когерентно-імпульсних радіолокаційних станцій від комбінованих завад: пат. 78120 Україна: МПК G01S 7/36. № u201210218; заявл. 28.08.2012; опубл. 11.03.2013, Бюл. №5.

16. Пиза Д. М. Метод формирования классифицированной обучающей выборки для автокомпенсатора помех при времяпространственной фильтрации сигналов / Д. М. Пиза, В. Н. Лаврентьев, Д. С. Семенов // Известия высших учебных заведений. Радиоэлектроника. 2016. - № 3. - C. 18-22. DOI 10.15588/1607-3274-2016-32.

17. Корн Г. Справочник по математике для научных работников и инженеров / Г. Корн. - М. : Наука, 1973. - 832 с. 